\title{
Paradigm of Ecotourism-Based Tourism Develoment in Context of Regional Economic Development Acceleration
}

\author{
Syaparuddin ${ }^{* a}$, Dearmi Artis *b \\ * Fakultas Ekonomi dan Bisnis Universitas Jambi \\ a Corresponding author: syappelawan@yahoo.co.id
}

ARTICLE INFORMATION ABSTRACT

Keywords:

Tourism, Ecotourism and

Integrative

\begin{abstract}
This research aims at analizing the progress of tourism sector development in Indonesia in relation to regional development dinamics and to analize tourism sector development model integratively. Analisys model used in this research is qualitative descriptive method. Coverage of analisys are the area which have tourism potetials or main tourism destination in Indonesia, having ability to develop rapidly. The progress of tourism will certainly accelerate regional development including its regional economy. The model of integrative ecotourism development can be applied by sinergizing regional and central government, as well as private sector and society in the frame of developing main infrastructure and its supporting facilities, human resources and ecotourims management.
\end{abstract}

\section{PENDAHULUAN}

Ketidak stabilan harga komoditas primer terutama produk - produk pertanian utama yang menjadi primadona penerimaan devisa negara seperti minyak kelapa sawit, karet olahan, dan beberapa produk mineral dan pertambangan seperti batubara, minyak bumi dan gas alam juga belum memperlihatkan trend pemulihan yang cukup menggembirakan. Flukktuasi harga produk-produk andalan ekspor Indonesia tersebut menyebabkan nilai ekspor Indonesia selama 4 tahun belakangan ini terus mengalami penurunan yang cukup signifikan.

Pada tahun 2011 total ekspor Indonesia mencapai angka 203.496,6 juta dollar, angka ini mengalami penurunan pada tahun-tahun berikutnya hingga periode 2015, dimana total ekspor Indonesia berjumlah sebesar 150 366,3 juta dollar, dengan demikian selama periode 20112015 total ekspor Indonesia mengalami penurunan rata -rata sebesar 7,29 persen pertahun. Sementara itu untuk indikator impor, angka - angkanya secara umum juga memperlihatkan trend penurunan walaupun pada tahun 2012 terjadi peningkatan. Pergerakan total impor Indonesia selama periode 2011 hingga 2015 mengalami penurunan rata - rata sebesar 5,30 persen, total impor Indonesia pada tahun 2011 berjumlah sebesar 177 435,6 juta dollar sedangkan pada tahun 2015 mengalami penurunan menjadi 142 694,8 juta dollar (Statistik Indonesia, 2016). Dampak negatif yang muncul sebagai akibat dari masalah eksternal tersebut adalahnya terjadinya penurunan pertumbuhan ekonomi yang apabila dilihat sisi pengeluaran selama periode 2011 sampai dengan 2015 terus memperlihatkan penurunan masing 6,17 persen pada tahun 2011 menjadi 4,79 persen pada tahun 2015 (BPS, 2016).

Dari aspek internal, persoalan krusial yang dihadapi antara lain meliputi kemiskinaan, ketimpangan distribusi pendapatan, pengangguran, melemahnya daya saing, defisi neraca pembayaran, ketimpangan pembangunan antar wilayah, menurunnya penerimaan pemerintah dalam struktur APBN dan meningkatnya beban utang luar negeri Indonesia, secara konsisten tentu akan mengureangi kapasitas kemampuan pemerintah untuk melaksanakan pembangunan sebagaimana yang telah digariskan.

Salah satu sektor yang mendapat perhatian penuh untuk dikembangkan dan terkait dengan pemanfaatan sumberdaya domestik adalah potensi sektor pariwisata. Wajah pariwisata Indonesia belum memberikan kontribusi optimal terhadap perekonomian wilayah dan perekonomian 
nasional, padahal potensi parawisata Indonesia sesungguhnya amat besar dan sangat menjanjikan.

Pengembangan sektor pariwisata secara masif pada dasarnya dapat memberikan manfaat positif bagi pembangunan ekonomi wilayah kedepan dan sekaligus akan memberikan efek pengganda (multiplier effect) terhadap berbagai variabel ekonomi domestik. Dalam tataran yang lebih luas pengembangan sektor pariwisata akan berkaitan dengan pengembangan ekonomi kreatif yang juga telah menjadi ikon utama untuk menjamin keberlanjutan proses pertumbuhan ekonomi. Berdasarkan kondisi dan permasalahan inilah, penting untuk diteliti paradigma pembangunan sektor pariwsata berbasis ecotourism dalam kaitannya dengan dinamika pembangunan ekonomi wilayah.

Penelitian ini bertujuan untuk menganalisis:
1. Perkembangan sektor
pariwisata Indonesia dalam kaitannya dengan dinamika pembangunan wilayah.

2. Model pengembangan kepariwisataan secara terintegratif

\section{TINJAUAN TEORITIS \\ Pariwisata}

Menurut Undang-undang Nomor 10 Tahun 2009 Pasal 1, Wisata adalah kegiatan perjalanan yang dilakukan oleh seseorang atau sekelompok orang dengan mengunjungi tempat tertentu untuk tujuan rekreasi, pengembangan pribadi, atau mempelajari keunikan daya tarik wisata yang dikunjungi dalam jangka waktu sementara. Pariwisata adalah berbagai macam kegiatan wisata dan didukung berbagai fasilitas serta layanan yang disediakan oleh masyarakat, pengusaha, Pemerintah, dan Pemerintah Daerah. . Sedangkan kepariwisataan adalah keseluruhan kegiatan yang terkait dengan pariwisata dan bersifat multidimensi serta multidisiplin yang muncul sebagai wujud kebutuhan setiap orang dan negara serta interaksi antara wisatawan dan masyarakat setempat, sesama wisatawan, Pemerintah, Pemerintah Daerah, dan pengusaha. Kepariwisataan diselenggarakan berdasarkan asas, a. manfaat; b. kekeluargaan; c. adil dan merata; d. keseimbangan; e. kemandirian; f. kelestarian; g. partisipatif; h. berkelanjutan; i. demokratis; j. kesetaraan; dan k. kesatuan

Selanjutnya Industri Pariwisata adalah kumpulan usaha pariwisata yang saling terkait dalam rangka menghasilkan barang dan/atau jasa bagi pemenuhan kebutuhan wisatawan dalam penyelenggaraan pariwisata. Sementara itu Kawasan Strategis Pariwisata adalah kawasan yang memiliki fungsi utama pariwisata atau memiliki potensi untuk pengembangan pariwisata yang mempunyai pengaruh penting dalam satu atau lebih aspek, seperti pertumbuhan ekonomi, sosial dan budaya, pemberdayaan sumber daya alam, daya dukung lingkungan hidup, serta pertahanan dan keamanan.

\section{Pembangunan Wilayah dan Pariwisata}

Pembangunan wilayah pada hakekatnya merupakan pembangunan yang proses penyelenggaraanya dilaksanakan dalam wilayah Negara Kesatuan Republik Indonesia berdasarkan asas pemanfaatan potensi sumberdaya yang ada dan bertujuan untuk mendinamisir dan mempercepat pertumbuhan ekonomi wilayah. Dalam upaya mempercepat laju pertumbuhan ekonomi tersebut Tidak dapat dipungkiri bahwa sektor pariwisata merupakan sektor strategis yang memiliki dampak nyata terhadap berbagai indikator utama pembangunan wilayah seperti struktur ekonomi, pendapatan wilayah, kesempatan kerja, daya saing wilayah, termasuk aspek - aspek non ekonomi yang memegang peranan penting dalam mewujudkan kesejahteraan masyarakat.

Selanjutnya, menurut Undang - Undang Pariwisata Nomor 10 Tahun 2009 tujuan penyelenggaraan kepariwisataan Indonesia adalah sebagai berikut : 1). Meningkatkan pertumbuhan ekonomi 2). Meningkatkan kesejahteraan rakyat
3).Menghapus kemiskinan 4).Mengatasi pengangguran 5). Melestarikan alam, lingkungan dan sumberdaya 6) memajaukan kebudayaan 7)mengangkat citra bangsa 8) memupuk rasa cinta tanah air 9). Memperkukuh jatidiri dan kesadaran bangsa. 10). Memper erat persahabatan antarbangsa.

Apabila diamati secara seksama tujuan dan prinsip - prinsip umum pembangunan kepariwisataan sebagaimana dikemukakan di atas, maka dapat digaris bawahi bahwa pembangunan pariwisata dengan pendekatan tersebut akan dapat dijadikan sebagai upaya untuk menumbuh kembangkan terwujudnya pembangunan ekonomi inklusif, karena didalamnya telah ada secara mendasar komponen utama yaknu melibatkan keikut sertaan masyarakat baik secara parsial maupun secara keseluruhan. Oleh karena itu pembangunan kepariwisataan harus dilihat sebagai bagian yang tak terpisahkan dari keinginan pemerintah dalam rangka menghadirkan pembangunan ekonomi inklusif yang intinya tidak 
lain adalah pembangunan untuk semua orang, tidak peduli latar belakangnya, agamanya, sukunnya, dan perbedaan - perbedaan lainnya (Prasetyantoko, dkk 2012) dalam Tambunan (2016). Lebih jauh sebagaimana diungkapkan oleh Raunia dan Kanbur (2009) dalam Tambunan (2016), dengan tepat menyatakan pembangunan ekonomi inklusif merujuk kepada sebuah pertumbuhan ekonomi yang dibarengi dengan kesempatan ekonomi yang sama bagi semua orang. Pembangunan ekonomi inklusif sangat focus pada kesempatan ekonomi dan aksesnya kepada semua anggota masyarakat dari semua golongan.

Peta jalan pengembangan pariwisata yang dirancang oleh kementerian pariwisata untuk tahun 2015 - 2019 dirumuskan dengan target sasaran sebagai berikut : 1. Meningkatkan kualitas dan kuantitas destinasi pariwisata. 2. Meningkatnya investasi disektor pariwisata 3. Meningkatnya kontribusi kepariwisataan terhadap penyerapan tenaga kerja nasional 4.Meningkatnya kontribusi pariwisata terhadap produk domestic bruto nasional 5.Meningkatnya jumlah kunjungan wisatawan manca Negara (wisman) 6. Meningkatnya jumlah penerimaan devisa 7. Meningkatnya jumlah perjalanan wisatawan nusantara 8.Meningkatnya jumlah pengeluaran wisatawan nusantara 9.Meningkatnya kapasitas dan profsionalisme SDM pariwisata.

Salah satu paradigma penting yang menjadi acuan utama pemerintah dalam mengembangkan sektor kepariwisataan di Indonesia adalah membangun dan mengetengahkan konsep ecotourism (wisata/pariwisata berbasis lingkungan atau ekologi). Konsep ini dihadirkan mengingat Indonesia merupakan negara yang amat kaya akan potensi wisata lingkungan yang memiliki nilai ekonomis tinggi, dan bahkan sebagian besar penerimaan negara dari sektor pariwisata pada dasarnya bersal dari wisata lingkungan ini (Kementerian Pariwisata dan Ekonomi Kreatif, 2012).

Wisata lingkungan (ecotourism) pada dasarnya merupakan konsep pengembangan kepariwisataan yang berbasis pada ketersediaan alam yang memiliki nilai ekonomi dan nilai sosial yang relatif tinggi. Menurut The International Ecotourism Society Wisata lingkungan (eco tourism) adalah responsible travel to the natural areas that converses the environment and improves the well-being of local people (TIES, 1990). (https://www.ecotourism.org/book/ecotourismdefinition). Dengan kata lain, pada dasarnya Konsepwisata lingkungan (ecotourism) merupakan pola kegiatan wisata yang memiliki hubungan dengan upaya melestarikan lingkungan hidup termasuk area wisata agar tetap alamiah, seiring dengan upaya untuk menghadirkan manfaat ekonomi bagi penduduk sekitar sekaligus memelihara keslestarian budaya masyarakat setempat.

Satu hal yang perlu dicermati secara mendalam dalam konteks pengembangan pariwisata berbasis lingkungan alam adalah masih dijumpai kendala-kendala struktural antara lain : 1) koordinasi antar para pihak yang belum optimal sehingga kurang memberikan daya dukung terhadap pengembangan pariwisata yang pada gilirannya akan memperkecil kontribusi pariwisata bagi perkeonomian baik dalam konteks nasional maupun regional. 2). Belum ada mapping yang komphrensif tentang potensi pariwisata pada setiap wilayah tujuan wisata sehingga sulit untuk mengkaji dan menetapkan potensi ekonomi pariwisata secara total baik dalam jangka pendek maupun dalam jangka panjang. 3). Penelitian dan pengkajian tentang aspek kepariwisataan dalam lingkup mikro yang mengkaitkannya dengan kondisi masyarakat setempat masih sangat terbatas dan belum banyak manghasilkan rekomendasi yang bermanfaat. 4). Pengembangan kepariwisataan dalam perspektif wilayah tidak terlalu melibatkan masyarakat sewtempat sehingga multiplier effect-nya terhadap masyarakat baik secara ekonomi maupun sosial tidak terlalu dirasakan oleh masyarakat. 5) pembangunan dan pengembangan sector kepariwisataan kadang kadang hanya dianggap sektor non basis sehingga dari sisi kebijakan pembangunan ekonomi wilayah dan dari sisi penganggaran mendapat porsi yang relatif kecil 6). Kendala keterbatasan anggaran pembiayaan pembangunan kerapkali menjadikan sektor pariwisata semakin tidak kompetitif sehingga sektor ini kurang dapat memberikan dukungan konstruktif bagi percepatan pembangunan ekonomi wilayah. Hal ini diperburuk lagi dengan ketidak mampuan pemerintah daerah setealah era otonomi daerah melakukan kerjasama dengan pihak swssta atau kalangan dunia usaha dalam hal pengembangan infrastruktur dan suprastruktur ke pariwisataan baik dalam jangka pendek maupun dalam jangka panjang'

\section{Model Pengembangan Kepari- wisataan Berkelanjutan \\ Menurut World Commission on Environment and Development (WCED), sebagaimana dikutip oleh Ike Janita Dewi (2011),}


pembangunan berkelanjutan adalah pembangunan yang memenuhi kebutuhan sekarang tanpa mengorbankan kemampuan generasi mendatang untuk memenuhi kebutuhan mereka. Untuk melaksanakan pembagunan yang berkelanjutan, pembangunan harus meningkatkan efisiensi secara ekonomis, melindungi dan memulihkan system ekologis dan meningkatkan kesejahteraan umat manusia. Sedangkan pembangunan pariwisata berkelanjutan (sustainable tourism development) adalah pembangunan berkelanjutan yang dicpai melalui kepariwisataan. Pembangunan berkelanjutan adalah pembangunan ekonomi yang berprospektif jangka panjang, yang menyeimbangkan manfaat eonomi dengan biaya lingkungan dan social. Pembangunan pariwisata yang berkelanjutan juga bertujuan untuk mewujudkan pertumbuhan kepariwisataan yang berkelanjutan. Pembangunan pariwisata yang menyeberkelanjutan dicapai dengan menyeimbangkan tiga elemen utama dalam pembangunan pariwisata yang berkelanjutan yaitu linkungan, ekonomi dan social yang menunjukkan prinsip umum dalam sustainable tourism yaitu :

1. Menyeimbangkan pemanfaatan lingkungan dengan manfaat ekonomis dari kepariwisataan.

2. Menyeimbangkan pemanfaatan sumber daya lingkungan dengan perubahan nilai social dan komunitas yang disebabkan oleh pengurangan sumber daya lingkungan,

3. Menyeimbangkan pertumbuhan ekonomi dan dampak pertumbuhan ekonomi pada nilai social dan ekonomi.

Istilah sustainable tourism dalam makna yang paling murni adalah industri yang mengupayakan untuk membuat dampak yang ringan terhadap lingkungan dan budaya lokal, sementara membantu untuk mendatangkan pendapatan, menciptakan lapangan kerja, dan konservasi terhadap ekosistem. Tanggung jawab ini mencakup lingkungan dan budaya yang sifatnya sensitive. WTO (World Tourism Organization) dalam situsnya menjelaskan sustainable tourism sebagai kepariwisataan yang mengarahkan kepada pengelolaan terhadap semua sumber yang dilakukan sedemikian rupa sehingga kebutuhan, ekonomi, social dan keindahan dapat terpenuhi sekaligus menjaga integritas budaya, proses ekologi yang esensial, keragaman hayati dan sistem pendukung kehidupan pada lingkungan yang bersangkutan (Getaways dalam Ni Made Ernawati, 2010).

\section{METODE PENELITIAN}

Metode analisis yang digunakan dalam penelitian ini adalah metode Deskriptif kualitatif sedangkan alat analisis yang digunakan untuk menganalisis perkembangan sektor pariwisata Indonesia dalam kaitannya dengan dinamika pembangunan wilayah dianalisis secara deskriptif, begitu pula untuk meyusun model pengembangan kepariwisataan secara terintegratif.

Data yang digunakan dari tahun 2010-2017 yang bersumber dari data publikasi Kementerian Pariwisata, Indonesia, 2017.

\section{HASIL PENELITIAN DAN PEMBAHASAN \\ Perkembangan Jumlah Wisatawan Asing di Indonesia}

Kemajuan dan perkembangan pariwisata suatu negara atau daerah terlihat dari salah satunya bagaimana angka jumlah wisatawan yang datang berkunjung dan melakukan perjalanan wisata ke negara atau daerah itu. Perkembangan jumlah wisatawan asing yang datang melakukan kegiatan wisata ke suatu negara atau daerah setiap tahunnya menjadi salah satu indikator penting dari perkembangan pariwisata.

Jika perhatian kita fokuskan pada angka total kunjungan wisatawan asing setiap tahunnya ke Indonesia selama 2015-2017 tergambar bahwa trend kunjungan wisatawan asing justru menunjukkan gejala stagnan pada angka kisaran 10 jutaan jiwa. Angka tertinggi terjadi pada tahun 2016 dengan total jumlah kunjungan wisatawan asing sejumlah 11.519.275 jiwa. Sedangkan pada tahun 2017 angka jumlah kunjungan wisatawan asing ke Indonesia tercatat hanya 9.254.589 jiwa, walaupun angka ini masih berupa angka sementara hingga bulan Agustus tahun 2017. Ini terkait dengan pengkoleksian data yang tersedia di Kementerian Pariwisata Indonesia yang baru mempublikasikan angka paling akhir hingga bulan Agustus 2017. Lebih detil, angka perkembangan jumlah wisatawan asing yang datang berkunjung ke Indonesia selama tahun 2015 hingga 2017 setiap bulannya dapat di lihat berikut ini pada tabel 3.1.

Tabel 1

Data Wisatawan Asing Ke Indonesia Perbulan Selama Periode Tahun 2015-2017 (Jiwa)

\begin{tabular}{|l|c|c|c|}
\hline BULAN & $\mathbf{2 0 1 5}$ & $\mathbf{2 0 1 6}$ & $\mathbf{2 0 1 7}$ \\
\hline Januari & 785,973 & 814,303 & $1,032,930$ \\
\hline Februari & 843,928 & 888,309 & 957,583 \\
\hline Maret & 841,071 & 915,019 & $1,066,588$ \\
\hline
\end{tabular}




\begin{tabular}{|l|c|c|c|}
\hline April & 801,873 & 901,095 & $1,142,180$ \\
\hline Mei & 852,388 & 915,206 & $1,150,067$ \\
\hline Juni & 872,385 & 857,651 & $1,111,616$ \\
\hline Juli & 877,584 & $1,032,741$ & $1,379,961$ \\
\hline Agustus & 911,704 & $1,031,986$ & $1,404,664$ \\
\hline September & 920,128 & $1,006,653$ & - \\
\hline Oktober & 877,798 & $1,040,651$ & - \\
\hline November & 835,408 & $1,002,333$ & - \\
\cline { 1 - 2 } Desember & 986,519 & $1,113,328$ & - \\
\cline { 1 - 2 } \multicolumn{1}{|c|}{ TOTAL } & $10,406,759$ & $11,519,275$ & $9,254,589$ \\
\cline { 1 - 1 } & &
\end{tabular}

Sumber : Kementerian Pariwisata, Indonesia, 2017.

Berdasarkan tabel 3.1, hal penting yang dapat kita highlight adalah bahwa jumlah kunjungan wisatawan asing ke Indonesia selama tiga tahun terakhir tidak banyak bergeser dari angka sepuluh jutaan wisatawan asing setiap tahunnya yang melakukan kunjungan wisata ke Indonesia. Bali masih menjadi pintu utama bagi sejumlah terbesar wisatawan asing kemudian Bandara SoekarnoHatta dan Batam.

Tabel 2

Data Wisatawan Asing yang Masuk Ke Indonesia Melalui 14 Bandar Udara Terbesar Di Indonesia Tahun 2015-2017 (Jiwa)

\begin{tabular}{|l|r|r|r|}
\hline \multicolumn{1}{|c|}{ Bandar Udara } & \multicolumn{1}{c|}{$\mathbf{2 0 1 5}$} & \multicolumn{1}{c|}{$\mathbf{2 0 1 6}$} & \multicolumn{1}{c|}{$\mathbf{2 0 1 7}$} \\
\hline Soekarno-Hatta & $2,429,924$ & $4,562,654$ & $1,836,105$ \\
\hline Ngurah Rai & $5,193,874$ & $4,599,434$ & $3,997,356$ \\
\hline Kuala Namu & 203,105 & 182,971 & 157,171 \\
\hline Batam & $1,247,122$ & $2,574,450$ & 999,909 \\
\hline Juanda & 209,522 & 184,867 & 157,490 \\
\hline Sam Ratulangi & 66,770 & 59,440 & 50,521 \\
\hline Minangkabau & 43,654 & 45,183 & 34,272 \\
\hline Adi Sumarmo & 5,665 & 20,975 & 4,245 \\
\hline Hasanuddin & 15,981 & 123,237 & 12,092 \\
\hline BIL, NTB & 109,392 & 101,626 & 84,606 \\
\hline Sepinggan, Kaltim & 4,364 & 38,518 & 3,389 \\
\hline Sultan Syarif K II & 34,636 & 31,092 & 27,487 \\
\hline Adi Sutcipto & 124,200 & 110,003 & 93,570 \\
\hline $\begin{array}{l}\text { Husein } \\
\text { Sastranegara }\end{array}$ & 134,091 & 122,128 & 106,663 \\
\hline Sumber : Kementerian Pariwisata, Indonesia, 2017.
\end{tabular}

Mengacu pada deskripsi sebelumnya, dapat dijelaskan bahwa wilayah-wilayah yang potensi objek wisatanya banyak atau daerah-daerah yang menjadi tujunan utama wisata di Indonesia, memiliki kemampuan untuk cepat berkembang. Perkembangan pariwisata tersebut sekaligus akan mempercepat pengembangan wilayah termasuk perekonomian wilayah.
Tabel 3

Rata-Rata Jumlah Tamu Asing Pada Hotel Berbintang Menurut Provinsi Tahun 2011-2015 (Ribuan Jiwa)

\begin{tabular}{|l|c|}
\hline \multicolumn{1}{|c|}{ Provinsi } & $\begin{array}{c}\text { Rata-Rata Wisman Pada } \\
\text { Hotel Berbintang }\end{array}$ \\
\hline Bali & $4.046,14$ \\
\hline DKI Jakarta & $1.283,96$ \\
\hline Kepulauan Riau & $1.216,18$ \\
\hline Jawa Barat & 388,86 \\
\hline Sumatera Utara & 266,32 \\
\hline
\end{tabular}

Sumber : Badan Pusat Statistik, Indonesia

Bali masih menjadi destinasi utama wisata di Indonesia yang menarik para wisatawan mancanegara. Hal ini dilihat dari rata-rata wisatawan asing yang menginap di hotel berbintang di Provinsi Bali periode waktu 20112015 yakni sebanyak 4.046.140 jiwa jumlah wisatawan mancanegara yang berlibur di Bali dalam periode waktu 2011-2015, kemudian DKI dan Batam.

Tabel 4

Penyerapan Devisa Wisatawan Mancanegara Tahun 2010-2014

\begin{tabular}{|c|c|}
\hline Tahun & Devisa Wisman (Juta US\$) \\
\hline 2010 & $7,603.45$ \\
\hline 2011 & $8,554.39$ \\
\hline 2012 & $9,120.89$ \\
\hline 2013 & $10,054.15$ \\
\hline 2014 & $11,166.13$ \\
\hline Rata-rata & $\mathbf{9 , 2 9 9 . 8 0}$ \\
\hline
\end{tabular}

Sumber : Devisa Wisman 1998-2014, Badan Pusat Statistik, Indonesia

\section{Model Pengembangan Kepariwi-sataan Secara Terintegratif}

Paradigma pembangunan kepariwisatan yang terintegraif adalah model pembangunan kepariwisataan yang dengan tegas berusaha untuk menciptakan suatu sinergitas kerjasama antara pihak pemerintah, penguasaha, masyarakat, dan para pihak lainnya dalam rangka untuk mempercepatkan pemberdayaan pariwisata sebagai ujung tombak pembangunan dan partumbuhan ekonomi wilayah.kerjasama yang ingin diwujudkan tersebut harus terangkum dalam satu kesepakatan yang bersifat operasional dan harus dapat diimplementasikan secara penuh dan berkesinambungan

Model pembangunan pariwisata yang terintegratif ini harus dijadikan pilar utama bagi wilayah - wilayah yang memiliki potensi sektor kepariwisataan untuk menumbuh kembangkan wilayahnya termasuk pengembangan kapasitas ekonomi masyarakat secara keseluruhan. Keterkaitan antara sektor kepariwisataan pada wilayah - wilayah tersebut dengan upaya untuk 
mendorong taraf hidup dan kualitas hidup masyarakat merupakan suatu keharusan oleh sebab itu keberlanjutan proses pembangunan ekonomi dan pertumbuhan ekonomi harus dibangun berdasarkan pilai utama dnamika pembangunan kepariwisataan.

Pilar utama pembangunan kepariwisataan dalam era sekarang ini harus bertumpu pada aspek : 1) sedapat mungkin mengoptimalkan potensi sumberdaya yang tersedia seperti alam, lingkungan, dinamika budaya dan social, 2) berupaya menjalin kerjasama dengan pihak investor yang memiliki keinginan kuat untuk membantu pengembangan kepariwisataan di wilayah - wilayah tujuan wisata, 3). memperhatikan secara seksama kualitas lingkungan hidup dan alam dari berbagai kerusakan yang dapat menghancurkan atau meniadakan nilai ekonomis dari potensi sumberdaya tersebut.

\section{Kerjasama antar Pemerintah}

Dalam kontek pengembangan

kepariwisataan khususnya Ecotourism secara terintegratif dapat dilakukan dengan pendekatan kewilayahan dan pendekatan kegiatan kepariwisataan yang terpadu. Pendekatan kewilayahan dapat diwujudkan dalam bentuk melakukan koordinasi diantara wilayah-wilayah yang memiliki potensi kepariwisataan terutama wisata ecotourisme. Wujud lainnya adalah menyusun perencanaan bersama misalnya dalam hal pembangunan infrastruktur jalan, pelabuhan laut, bandara dan infrastruktur lainnya, sehingga wilayah-wilayah ini akan terhubung dengan baik satu dengan lainnya. Pengintegrasian dapat pula dilakukan oleh pemerintahan yang lebih tinggi, misalnya integrasi antar provinsi dapat pula dilakukan oleh pemerintah pusat, pengintegrasian antar kabupaten/kota dilakukan oleh provinsi.

Bentuk lainnya adalah peningkatan sumber daya manusia secara terintegrasi, dimana pengelola pariwisata khususnya ecotourism saling memahami dengan baik tentang objek-objek ecotourism pada masing-masing wilayah dan wilayah yang terintegrasi teresbut. Hal ini sangat penting mengingat pada wilayah yang terintegrasi terutama secara geografis sangat memungkinkan para wisatawan akan melanjutkan perjalanan wisatanya pada wilayah yang terintegrasi tersebut. Promosi dalam bentuk pamflet atau bentuk lainnya yang mudah untuk menyebarkan informasi tentang objek wisata Ecotourism daerah-daaerah terintegrasi harus tersedia. Intinya adalah semua wilayah yang terintegrasi harus mempromosikan atau memahami dengan baik tentang masing tentang objek wisata Ecotourism baik didaerah masing-masing maupun daerah lain dalam kawasan yang terintegrasi. Pengintegrasian dalam kontek ini dapat dilakukan antar provinsi dalam suatu Negara maupun antar kabupaten/kota dalam satu provinsi.

Model pengintegrasian pengembangan ecotourism dalam mempercepat pembangunan antar wilayah dapat pula dilakukan dengan melakukan promosi bersama baik di dalam maupun di luar negeri. Keuntungan dari promosi bersama ini diantaranya adalah lebih efisien dari sisi biaya dan lebih efektif dari sisi penyampaian informasi-informasi penting yang terkait dengan potensi dan objek Ecotourism pada wilayah yang terintegrasi.

Kerjasama antar pemerintah dapat pula dilakukan dengan pemerintah pusat. Kerjasama dimaksud dapat berupa pembangunan fasilitas yang berhubungan dengan pengembangan kepariwisataan yang didanai oleh pemerintah pusat atau ditanggung bersama antara pemerintah daerah dan pemerintah pusat. Disamping itu dapat pula dilakukan dengan mempromosikan objek pariwisata Ecotourism terutama ke luar negeri. Selain bersinergi dalam pengembangan infrastruktur dan promosi, peran pemerintah pusat dalam pengembangan pariwisata Ecotourism di daerah dapat juga berupa pembinaan dalam pengelolaan atau manajemen kepariwisataan.

\section{Kerjasama dengan Penguasaha atau Masyarakat}

Pihak swasta dapat berperan penuh ataupun sharing dengan pemerintah dalam pengembangan fasilitas utama maupun fasilitas penunjang ecotourism. Pemerintah menyediakan sarana utama seperti jalan, pelabuhan dan pihak swsata menyediakan sarana penunjang lainnya. Sinergi antara pemerintah (pusat dan daaerah) dengan pihak swasta dapat juga berbentuk promosi baik melalui media Televisi dan media cetak, maupun melakukan promosi langsung ke luar negeri. Perusahaan-perusahaan penerbangan, pelayaran maupun pengelola travel perjalanan dapat pula menjadi sarana untuk mempromosikan Ecotourism ini.

Kerjasama atau sinergi yang lain dapat pula dilakukan untuk pengelolaan ecotourism. Kerjasama dimaksud dapat dilakukan secara penuh oleh pihak swasta untuk objek ecotourism tertentu dengan system pengelolaan tertentu, pemerintah atau pemerintah daerah hanya mendapatkan bagi hasil. Tanggung jawab terhadap 
fasilitas utama dan peunjang semua menjadi tanggung jawab swasta. Dalam konteks seperti ini pemerintah harus selalu mengawasi agar objek pariwisata yang ramah lingkungan tetap terjaga. Pengembangan SDM kepariwisataan juga dapat menjadi bagian dari bentuk sinergi atau integrasi antar berbagai pihak. Wujudnya dapat berupa pengayaan akan pemahaman kepariwisatan, pengelolaan dan pengembangannya.

Partisipasi masyarakat atau keterlibatan masyarakat dalam pengembangan Ecotourism juga sangat penting. Keterlibatan tersebut dapat berupa partisipasinya dalam pengelolaan pariwisata maupun dalam menjaga linkungan objek wisata. Masyarakat sekitar objek wisata akan mendapatkan manfaat terutama manfaat ekonomi dan sosial maupun manfaat dari adanya pembanguan saranan dan prasarana pengembangan pariwisata.

\section{Permasalahan Pengembangan Ecotourism di Indonesia}

1. Infrastruktur

Secara umum infrastruktur baik utama maupun penunjang masih menjadi salah satu masalah yang dihadapi di beberapa objek wisata di Indonesia. Potensi wisata yang luar biasa terkadang tidak dapat dinikmati oleh masyarakat karena tidak ada atau kurangnya infrastruktur seperi jalan menuju objek wisata tersebut, termasuk juga infrastruktur komunikasi, listrik dan air bersih. Jauhnya objek yang akan dituju dan tidak didukung oleh sarana penunjang seperti penginapan dan lainnya juga menyulitkan pengembangan ecowisata di Indonesia.

2. Pemasaran Objek

Jika ditelusuri lebih jauh, ternyata masih banyak objek wisata yang belum dikenal di masyarakat luas akibat kurangnya pemasaran atau promosi yang dilakukan pihak terkait, padahal objeknya sangat bagus dan sangat menjajikan. Banyak objek wisata bukan asli menjadi sagat terkenal karena pemasarannya yang sangat baik

3. Sumber daya manusia

Ketersedian dan kualitas SDM kepariwisataan menjadi faktor yang penting dalam pengembangan pariwisata terutama Ecotourism. Kemampuan SDM tidak hanya terbatas pada kemampuan komunikasi, tetap juga pada aspek menciptakan peluang-peluang baru sebagai pendukung perkembangan ecotourism tersebut.

4. Kesadaran Masyarakat

Kesadaran masyarakat dalam menjaga lingkungan diseputar objek wisata menjadi masalah tersendiri dalam pengembangan objek wisata, terutama yang berdekatan dengan pemukiman masyarakat. Banyak kita jumpai objek wisata di Indonesia yang dulunya indah dan bersih menjadi kotor dan terkesan kurang diperhatikan.

5. Globalisasi dan liberalisasi

Pola pikir masyarakat yang lebih berorientasi berwisata ke luar negeri, juga dapat menghambat pengembangan pariwisata di Indonesia.

6. Terbatasnya anggaran pemerintah

Persoalan lain terkait dengan pengembangan Ecotourism adalah kemampuan anggaran pemerintah termasuk pemerintah daerah yang terbatas. Sehingga pengembangan Ecotourism menjadi kendala untuk dikembangkan.

\section{KESIMPULAN DAN SARAN Kesimpulan}

1. Perkembangan sektor pariwisata di beberapa wilayah yang potensi wisatanya relative baik berpotensi dan telah terbukti dalam mempercepat pembangunan wilayah.

2. Pengembangan ecotourism secara terintegratif dapat dilakukan dengan mengitegrasikan berbagai unsur yakni pemerintah, pemerintah daerah, swasta (pengusaha) dan masyarakat. Integrasi dapat diujudkan dalam pengembangan infrastruktur, pengembangan SDM, pemasaran maupun pengelolaan.

\section{Saran}

1. Kepariwisataan telah terbukti menjadi daya dorong percepatan pengembang wilayah, oleh karenanya penting bagi daerah yang memiliki potensi wisata terutama Ecotourism untuk mendorong pengembangan kepariwisataannya

2. Pengembangan kepariwisataan secara terintegratif menjadi salah satu model yang sangat mungkin untuk dikembangkan dimasa yang akan datang dalam kerangka pengembangan kepariwisataan di Indonesia. 
DAFTAR PUSTAKA

Badan Pusat Statistik, (2015). Statitik Kunjungan

Wisatawan Mancanegara (international Visitors Arrival Statistics) 2014.

Badan Pusat Statistik, (2016). Statistik Indonesia 2016

Badan Pusat Statistik, (2016). Laporan Bulanan Statistik Indonesia 2016

Ike Janita Dewi, 2011. Implementasi dan Implikasi Pemasaran Pariwisata yang Bertanggungjawab (Responsible Tourism Marketing). Kementrian Kebudayaan dan Pariwisata Republik Indonesia

Kementerian Pariwisata dan Ekonomi kreatif bekerjasama dengan ILO, (2012). Rencana Strategis Pariwisata Berkelanjutan dan Green Jobs untuk Indonesia.

Konsep ecotourism (2016) http://www.merriamwebster.com/dictionary/ecotourism

Konsep ecotourism (2016) https://www.ecotourism.org/book/ecotourism-definition Konsep ecotourism (2016) https://en.wikipedia.org/wiki/Ecotourism

Kurniawati Rina . Pariwisata Berkelanjutan. Tanpa tahun

Ni Made Ernawati, 2010. Tingkat Kesiapan Desa Tihingan-Klungkung, Bali Sebagai Tempat Wisata Berbasis Masyarakat. Jurnal Analisis Pariwisata Volume. 10 No. 1 Th. 2010.

Ratman Rozki Dadang, (2016). Strategi Pengembangan Kepariwisataan. Deputi Bidang Pengembangan Destinasi dan Industri Pariwisata. Powerpoint yang disajikan pada Musrenbang Penyusunan RKPD Provinsi Kalimantan Seloatan Tahunj 2017 Banjarbaru, 11 April 2016.

Tambunan Tulus, (2016). Pembangunan Ekonomi Inklusif Sudah Sejauh Mana Indonesia. Penerbit LP3ES, Jakarta, Cetakan pertama.

Undang -Undang Nomor 10 Tahun 2009 tentang Kepariwisataan. 